\title{
CHIN RADIO AND ITS LISTENERS: A NEGOTIATION IN THE POST-WAR COMMERCE OF ETHNICITY
}

\author{
MiChele Amatiello
}

\begin{abstract}
Summary: Canadian broadcasting underwent a period of transition following the Second World War. Government officials attempted to restructure radio to serve as an instrument for assimilation which would assist new Canadians in understanding Canadian culture and customs. In 1966, CHIN Radio AM 1540 was formed in Toronto by Johnny Lombardi. It became Ontario's first foreign-language radio station. This study asserts that CHIN Radio provided its listeners an opportunity to negotiate their ethnicity on a daily basis, while it simultaneously worked to assist new Canadians to learn about Canadian culture and customs. These listeners must be viewed as active protagonists, who actively took advantage of the services and entertainment CHIN provided.
\end{abstract}

The formation of CHIN radio occurred during a time of transition within Canadian broadcasting. Government officials were concerned with assisting the very large number of immigrants who arrived in Canada following the Second World War. In this effort they turned to radio broadcasting and re-structured it to function as a post-war tool which would assist new Canadians in understanding Canadian culture and customs. Their ultimate aim was to foster "good." Canadian citizens. ${ }^{1}$ Foreign-language programming would no longer be regulated in a lackadaisical manner, as it had been before World War II. Instead, it would work to address the post-war immigration "problem." This paradigm shift altered what was then referred to as "ethnic" broadcasting.

The catalyst behind the re-structuring was the Board of Broadcast Governors' (BBG) public announcement issued in 1962 with the title "Public Announcement: Foreign-language Broadcasting." The announcement established a new framework within which pioneers in foreign-language broadcasting, like CHIN founder Johnny Lombardi, would operate. Many of these pioneer broadcasters had been airing foreign-language programmes on various stations across the country long before the BBG inter-

1 CRTC, "Ethnic Broadcasting," 4-9. 
vened in their affairs. After the 1962 announcement, however, they could apply for official licenses of their own as long as their proposed stations met the government's criteria. The three-page document emphasised the ways in which these stations were to help new Canadians to "learn something of Canadian history, geography and government at three levels; assist the newcomer to understand English or French by special programmes that have this end in view; stimulate the listeners' pride in Canadian citizenship; and generally make them feel at home in Canada." 2 While the government's assimilationist agenda is clear, questions remain regarding the influence of these changes on foreign-language radio listeners.

CHIN radio AM 1540 officially began broadcasting on Monday 6 June 1966 and so, four years after the BBG's announcement, became Ontario's first foreign-language radio station. CHIN broadcasted in over thirty languages as it was rewarded with an additional frequency, 100.7 FM, in 1967. The FM frequency allowed CHIN to provide expanded broadcasting to its largest market, Italian listeners, without neglecting other language markets. Italian listeners could tune in Monday to Friday from 7:00 AM to12:00 PM on 1540 and switch over to 100.7 from 12:00 PM to 7:00 PM. On Saturday Italian-language programming aired from 8:00 AM to 5:00 PM on 1540, while Sunday it aired from 9:00 AM to 5:00 PM on 100.7.

CHIN's audience was a diverse group of people who came from a wide range of ethnic backgrounds and ages. Some of these listeners were recent immigrants, others were Canadian born. This group also encompassed different occupational backgrounds. They were not all "housewives" as was assumed by government officials according to the 1962 announcement. ${ }^{3}$ An analysis of the station's broadcast programming and cultural events is the best method to understand CHIN's audience and to comprehend fully the day-to-day reality of the station's operations in the postWorld War II era. It illustrates CHIN's importance for Toronto's ethnic population. Was the station simply a tool, which attempted to assert Ottawa's assimilationist objectives? Did CHIN strive to integrate ethnic cultures into mainstream Canadian society? Some members of the ItalianCanadian community - for example, popular author Nino Ricci-have been critical of CHIN and the Italian-Canadian media in general. Ricci feels that the Italian-Canadian media thrives on ethnic nostalgia which perpetuates both ethnic stereotypes and sentimentality. ${ }^{4}$

1 CRTC, "Ethnic Broadcasting," 4-9.

2 Board of Broadcast Governors, "Public Announcement," 1.

3 Umberto Manca interview. Also see Board of Broadcast Governors, "Public Announcement," 1.

4 Ricci, "A Critique," 44. 
While Ricci makes many interesting points, he fails to understand the active audience, which shaped much of the station's broadcasting. This study argues that CHIN Radio offered its listeners an opportunity to negotiate their ethnicity on a daily basis, while it simultaneously worked to assist new Canadians to understand Canadian culture and customs. These listeners must be viewed as protagonists, who actively took advantage of the services and entertainment CHIN provided. People listened to CHIN Radio for practical reasons; they wanted to be both informed and entertained. In addition, it created commercial opportunities for ethnic and other groups; allowing them to participate in what can be understood as the post-war commerce of ethnicity. The station broadcast its programs in several languages and organized countless community events during this period. It would be impossible to review adequately all of the groups reached by the broadcaster and all of the promotional activities undertaken with those groups over the years. Instead, the analysis will focus on the station's Italian-language programming and its promotion of the CHIN International Picnic.

CHIN Radio's early history begins with the services and entertainment it was able to provide for Toronto's Italian-Canadian community before the 1962 announcement by the BBG. CHIN's precursor was the Johnny Lombardi Show, a weekly program hosted by Lombardi. This program's broadcast language was mainly English but Lombardi also played Italian music which catered to Toronto's massive influx of post-war southern-Italian immigrants. CHIN initially struggled to find a successful programming format when it first went on air in the mid 1960s. Its "cosmopolitan flavor" strategy was eventually replaced by a full day, multi-lingual format, as the station tried to become the new Canadian's guide to "good" citizenship.

Umberto Manca began working at CHIN in the late 1960s as a broadcaster and eventually as the director of the station's Italian-language programming. He emphasises that a clear distinction must be made between "assimilation" and "acculturation" and that these two words cannot be used interchangeably. According to Manca, assimilation implies the complete absorption of another society's culture, traditions and beliefs. In contrast, acculturation allows one to partake in the host society social life while maintaining an original cultural heritage. He feels CHIN Radio helped Italian immigrants by bridging a gap between two cultural identities. ${ }^{5}$ Academics have also commented on the complexities of ethnic identity. The work of Conzen, Gerber, Morawska, Pozzetta and Vecoli reminds us that ethnicity cannot be distinguished simply by birth certificates, passports, or one's family background. These scholars note that ethnic identity

5 Angelo Manca interview. 
is best understood as a concept that is negotiated on a daily basis by both groups and individuals. ${ }^{6}$ Decisions are constantly made regarding which aspects of "foreignness" are to be preserved and which aspects of "Canadianness" are to be embraced. These negotiations can be made with one's self, within an ethnic group, between various ethnic groups or between ethnic groups and the dominant culture. Conzen et al. refer to this as being a part of the "dual construction of ethnicity."7 Negotiating ethnicity becomes more perplexing when both the children of immigrants and interethnic marriages are factored into the equation. All of these negotiated complexities shaped the structure of CHIN's programming format.

CHIN's Italian-language programming content was not merely influenced by bureaucratic regulations. The BBG's new mandate provided an important framework within which the station was to operate; this mandate remained intact when the BBG was replaced by the Canadian Radio and Television Commission (CRTC) in 1968. Nevertheless, the demands of the listener cannot be forgotten. Manca notes that CHIN attempted to balance the wide interests of its audience because listeners frequently called in with their criticisms. Generally, the older members of the community requested traditional Italian music, while members of the younger generation requested more contemporary songs. Men often called in demanding that more broadcast time should be allocated to sports coverage, while some women complained that too much time was devoted to sports. There were also those within the community who called in with specific requests. For example, injured labourers asked for broadcasts which discussed workers compensation. ${ }^{8}$ In short, CHIN's audience played a dominant role in shaping the arrangement of its Italian-language programming.

The station's shows featured practical information which was aimed particularly towards assisting new-Canadian members of its audience. Lawyers participated in broadcasts from the station to help clarify legal issues. ${ }^{2}$ Legal information also was offered by members of Toronto's Metropolitan Police. For example, by 1969 Police Constable Tony Cecchetto was a frequent contributor to CHIN's "Open Mike" programme. ${ }^{10} \mathrm{He}$ explained the essence of his two-hour weekly broadcast, "We get calls asking about the demerit system, cross-walks ... and then there's

${ }^{6}$ For an American study regarding the negotiation of ethnicity see Kathleen Neils Conzen et al., "The Invention of Ethnicity," 3-41.

7 Conzen et al., "The Invention of Ethnicity," 5-6.

8 Manca interview.

9 Manca interview.

10 Aubrey V. Potter letter. 
the guy who calls in and asks me 'Do you think it's fair that I got this ticket?"' 11 Cecchetto was originally slated to appear on the station for one broadcast. However, his Tuesday-night programme quickly became popular and more shows followed. On some nights, CHIN received "as many as 3,000 calls" during Cecchetto's show. ${ }^{12}$ The station also had other public service shows. Doctors went on air to provide medical information. Businesses sometimes called in to inform the station of job offers, which CHIN would relay to its audience. In 1969 employees of the Department of National Revenue broadcast on CHIN to distribute income tax information to its audience. ${ }^{13}$ The station advertised many of the free services available for Italian immigrants abroad which were provided by Italian government. These services were organized by Italy's Patronato offices through its Istituto Nazionale Assistenza Sociale (INAS) agency. INAS offered new Italian Canadians a wide range of general services which included helping them to understand and fill out important documents and forms. ${ }^{14}$

The public service information CHIN supplied did not go unnoticed by officials in Ottawa. E.J. Gibbons, a member of the Information Division of the Dominion Bureau of Statistics, wrote a personal letter on 7 March 1967 addressed to Johnny Lombardi. He expressed appreciation for "the kind offer of free radio time for public service announcements." 15 He went on to note, "It is very gratifying to know that so many public spirited people are devoting time and energy to the Italian immigrants on a particularly voluntary basis." 16 Thus, CHIN's Italian-language broadcasting worked to appease both its listeners within Toronto's Italian-Canadian community and government officials.

CHIN's daily newscasts played a central role in keeping its listeners informed. The Italian-language newscast featured Canadian and international news coverage and paid particular attention to events in Italy. ${ }^{17}$ CHIN's listeners were interested in news and popular culture from Italy because it allowed them to stay connected with family and friends living overseas. In 1973, accountant Antonio Marcellino informed the Toronto Star that he had followed Italian politics and soccer closely since arriving in Toronto in 1960. He explained that he kept in touch by reading Corriere

\footnotetext{
11 Public Archives of Canada, 9.

12 Public Archives of Canada, 49.

13 Ralph Parkinson letter.

14 Manca interview.

15 E.J. Gibbons letter.

16 E.J. Gibbons letter.

17 CHIN Radio, History of CHIN.
} 
Canadese, the city's Italian-language newspaper, and by listening to CHIN. ${ }^{18}$ For recent arrivals like Marcellino, CHIN made them feel at home in a strange land. Marcellino's original plan had been to move to Toronto with his wife for about five years, earn and save some money, and then return to Italy. He asserted, "Canada is my home now. I enjoy the way of life. We have four children and we believe Toronto is the best place to raise them." 19 CHIN's newscasts and interviews were particularly important for many Italian Canadians who were active politically, not only voting in Canadian elections (if they had officially obtained Canadian citizenship) but in Italian-national elections from their new communities in Canada. ${ }^{20}$ In fact, as the work of Mark Hayward effectively illustrates, the Italiani all'estero (Italians abroad) continue to influence the outcomes of Italian elections in the twenty-first century. ${ }^{21} \mathrm{CHIN}$ 's audience also used the station as a means to respond to national emergencies in Italy. For example, people reacted in 1969 when news was announced that an earthquake in Sicily had killed an estimated 300 people. According to the Italian-language newspaper Il Giornale di Toronto, CHIN received financial aid from several generous donors after the station initiated the "Fondo per la Sicilia" (Aid for Sicily) fundraiser. The station was able to raise twentythree thousand dollars in a short period with the support of Toronto's Italian-origin community. ${ }^{22}$ According to the Toronto Star the total reached an estimated thirty-eight thousand dollars within five days. ${ }^{23}$

While CHIN offered educational public service programmes and news information, it also entertained its audience with music and sports. In terms of music, the station's management maintained the same formula which Lombardi had used from when he began broadcasting. Over time, CHIN mixed popular Italian songs from established artists like Mina and Pino Daniele with songs from emerging artists such as Nek and Laura Pausini in order to appeal to listeners of all ages. The blending of past and contemporary songs varied daily based on the radio host, listener requests, and upcoming events or record releases the station was attempting to promote. The station supported its music programming by hosting various concerts or organizing festivals which featured Italy's top popular performers in the post-World War II era like Zucchero and Gianni Morandi. For

18 Public Archives of Canada, 154.

19 Public Archives of Canada, 154.

20 Manca interview.

21 Mark Hayward, "Global Italy," 1-10.

22 Public Archives of Canada, 27.

23 Public Archives of Canada, 27. 
example, in 1972 CHIN presented "Il Leone Di Napoli" (the Lion of Naples) Massimo Ranieri for two shows at the O'Keefe Center in Toronto. ${ }^{24}$ The concerts were marketed as two "super spettacoli" (super shows) as Ranieri was coming to Toronto "Dall'Italia con amore ... in persona" (from Italy with love and in person). 25 In addition, the station developed Italian-Canadian talent by hosting song competitions for local artists and by playing their music on air. Some of these musicians had their work recorded by Lombardi's own record company, Bravo Records and Music Co. Ltd., which he launched in the 1950s. By the 1970s, the label had produced close to two hundred albums featuring performers from various ethnic groups. ${ }^{26}$ The label also began to re-record some Italian music in Canada and translated English-language recordings for ethnic groups. ${ }^{27}$ All of this was part of a strategy used to respond to the thirty-percent Canadian content rule that the CRTC gradually implemented in the early 1970s for all radio stations. Lombardi exclaimed to a Globe and Mail reporter on 8 March 1971, "Owning the second company (Bravo Records) has saved my skin ... I'm making my own Canadian content." 28 Thus, promoting Italian-Canadian performers not only enhanced the station's image within Toronto's Italian-Canadian community: it also appeased the CRTC because it increased the station's Canadian content even though the majority of this music material was performed in a foreign language.

CHIN's sports coverage was organized in a similar way to its newscast; it was a hybrid which examined both the North American and international sports scene. CHIN followed Italy's sports scene closely and this distinguished it from other stations in Toronto. Management devoted much of its attention to soccer and, in fact, CHIN marketed itself as "Toronto's Soccer Radio Station." 29 The station chronicled Italy's quests for the World Cup and the games played in the Italian "Serie A" or first division commercial soccer league. In addition, CHIN also promoted North American soccer by carrying broadcasts of National Soccer League games. ${ }^{30}$ Manca explained that soccer coverage was important because it attracted youth, particularly young men, who might not otherwise tune in to CHIN. ${ }^{31}$ Lombardi did a

24 Public Archives of Canada, 133.

25 Public Archives of Canada, 133.

26 Public Archives of Canada, 92.

27 Public Archives of Canada, 90.

28 Public Archives of Canada, 90.

29 Public Archives of Canada, 166.

30 Public Archives of Canada, 123.

31 Manca interview. 
great deal of work to promote soccer across the city. In 1972, he organized a public television viewing of a European Cup game between the Italian first-division club F.C. Inter Milan and the Scottish-league team Celtic F.C. at Maple Leaf Gardens. ${ }^{32}$ By 1973, he was supporting the launch of an indoor soccer league in Toronto known as the World Indoor Football League. According to the Ryersonian, the league targeted "the ethnic community" because fans could go to the Maple Leaf Gardens and "cheer their favorite teams" like "the Toronto Portuguese" or the "the Toronto British" to victory. 33 Lombardi also made time to play the game. For example, he scored a goal in CHIN's 2-1 victory over the team staffed by the Toronto Sun newspaper during a promotional exhibition game in 1972.34

While CHIN placed a great deal of emphasis on soccer, it also covered other sports stories of interest to its listeners. For example, its Olympic coverage devoted attention not only to the performance of Canadian athletes but Italian athletes as well. ${ }^{35}$ Overall, CHIN's Italian-language programming offered listeners an opportunity to negotiate their complex ethnic identities: the station's broadcast content was a unique mixture of material which interested its Italian-Canadian audience. The station's listeners played an active role in influencing the station's programming and they took full advantage of the services and entertainment offered by CHIN Radio. The station constantly worked to appease not only government officials but Toronto's Italian-Canadian community. While CHIN's programming was an important means of communication for Toronto's post-war Italian-Canadian community, however, it is also important to consider the role of the annual CHIN Picnic in this regard.

The CHIN International Picnic is the largest and longest running event promoted by the station. The picnic is more than a celebration of Italian culture and heritage. It functions as a manifestation of Lombardi's aim to bring together Toronto's diverse ethnic community; to create a sense of public space for many individuals who had long considered themselves as outsiders to the dominant culture. It began in July of 1966 to celebrate the official license CHIN had just received from the BBG. An estimated seven thousand people arrived at Toronto's Centre Island to participate in the festivities. ${ }^{36}$ Another reason for holding the picnic was to quash uncertainties advertisers held regarding the size of the station's audience base.

32 Public Archives of Canada, 120.

33 Public Archives of Canada, 135.

34 Public Archives of Canada, 128.

35 Manca interview.

36 Joe Serge, "CHIN's Johnny Lombardi." 
CHIN was at this time unable to join the Bureau of Broadcasting Measurement (BBM), an organization which measured listener ratings for radio and television stations across Canada. ${ }^{37}$ The BBM only tracked English- or French-language programmes. ${ }^{38}$ Thus, no official ratings were available (aside from privately conducted surveys) which could be used to illustrate CHIN's audience base for businesses interested in advertising with the station. The positive turn out for CHIN's first picnic led to the creation of the National Spaghetti Day and Picnic in 1967: it was commonly referred to as the Spaghetti Dig-In by many newspapers. 39 The DigIn was held at Toronto's Centre Island and was co-hosted by Lombardi and "Bad Boy" Mel Lastman who was outfitted in his distinctive "jailbird" outfit. The festival was centered on a spaghetti-eating contest which attempted to attract CHIN's Italian-Canadian listeners. In its first year, twelveyear-old Tony Canestrale from Toronto won the Junior Division of the competition, while Pasquale Melfi from Hamilton was victorious among the older contestants. Melfi was awarded with a free trip to Rome for his effort. 40

Over time, the picnic expanded in size and became a multi-day, multicultural festival which presented an increasing number of attractions including, among other features, concerts, folk-dancing competitions, baby-crawling challenges, and the controversial bikini contest. The event drew massive crowds annually and effectively illustrated that people were indeed listening to CHIN. In 1968, the Toronto Transit Commission (TTC) wrote a letter to Lombardi congratulating him on the success of the picnic. According to the TTC, "32 extra buses to accommodate the some 43, 000 passengers" were required for the "heavy to capacity traffic on the Bay (Street) bus route from 9:00 a.m. to 3:30 p.m. and from 4:00 p.m. to 12:30 a.m. for the homebound traffic." 41 In 1971, the Toronto Star noted that roughly fifty thousand people showed up at Centre Island to attend the picnic, a figure which suggests that its attendance clearly had grown over the years. 42

The picnic's formative years did not always run smoothly. There were open air outdoor stoves which cooked the pasta poorly and the pasta contests were frequently delayed. Lombardi noted, "We survived. Everybody,

\footnotetext{
37 Public Archives of Canada, 164.

38 David Lewis Stein, "Lombardi is still entitled."

39 Public Archives of Canada, 18.

40 Public Archives of Canada, 18.

41 Toronto Transit Commission letter.

42 Public Archives of Canada, 108.
} 
including the contestants, (who) ate the most horrible-tasting pasta ever, stuck together." 43 The picnic changed locations in 1982 from Centre Island to the grounds of the Canadian National Exhibition, located near Toronto's waterfront. Lombardi explained, "it is no longer a delight to go to the Island if one has to wait in line for two to three hours (for a ferry boat ride). At the Ex we can carry on till midnight, and we don't have to worry about missing the last boat home. I know what that's like, because it happened to me." 44 By the 1990s the event's operating cost was about two million dollars, and it was attracting over 300,000 people from all over North America. ${ }^{45}$ The picnic became an annual summertime tradition in Toronto which brought its diverse community together for both food and fun. The festival was a living manifestation of what CHIN was attempting to accomplish with its radio programming on a daily basis. ${ }^{46}$

The CHIN Picnic and similar festivals have been condemned by some. In 1985, Lombardi was criticized by an unidentified "multicultural media expert" in a Globe and Mail article. The unidentified individual asserted, "Lombardi operates a strictly commercial venture ... He's trading on the whole issue of multiculturalism. The image given by him is the soft sideit's the wall-to-wall music, picnics, contests-there's a lot left to be desired." 47 Italian-Canadian author Nino Ricci has openly disapproved of the picnic. In an article written for EyeItalian magazine, while referring to a variety of important political and social issues, Ricci stated, "And it's not the kind of thing that's likely to come up at the CHIN Picnic." 48 Multicultural festivals have also been critiqued by academics. Cynthia Thoroski, amongst others, has asserted that ethnic folk festivals reveal little information regarding cultural groups and their customs which are placed on display. She explains that these events must be viewed as both a "homogenization and commodification of ethnicity" which allows spectators "the illusion of a cross-cultural close encounter along with the security of imagining the 'other' from a safe distance." 49 While Thoroski's claim is based on her study of Winnipeg's Folklorama festival, it can be argued that the CHIN Picnic was more than simply a "fast-food-like production

43 Evasuk, "Johnny Lombardi."

44 MacNiven, "The king of radio."

45 Serge, "CHIN's Johnny Lombardi." See also Small, "Lombardi."

46 Lombardi inteview.

47 Kingwell, "Johnny Lombardi ...".

48 Ricci, "Confession ..."

49 Thoroski, "Adventures in Ethnicity," 106.

50 Thoroski, "Adventures in Ethnicity," 107. 
of ethnicity." 50 The event was both politically and culturally relevant to the epoch in which it was formed, as it allowed Toronto's post-war ethnic communities, including those of Italian origin, to negotiate their complex identities and to feel a part of mainstream Canadian society.

The annual picnic began before Canada officially embraced its policy regarding multiculturalism. Toronto was still very much a city of cleavages and a great deal of anxiety existed within the city's Anglo-Saxon population regarding the post-war "immigration problem." The festival brought Toronto ethnic groups together and it packaged ethnicity as something which was not to be feared but to be embraced. Many of the advertisements for the event stressed the picnic's family-friendly environment. In one promotional advertisement, Bob Rae (then a member of the New Democratic Party) encouraged all Torontonians to attend the 1987 Picnic. He asserted, "Arlene (his wife) and I hope to see you at the celebrations. Bring your family and have a good time." 51 The picnic was always marketed as a wholesome place for both ethnic and non-ethnic nuclear families. In many respects, this marketing strategy reflected much of the craze expressed in the early post-war era for the importance of children and families. 52 This helps explain the popularity of children's events like the Baby Crawling Derby. This race engaged large crowds of screaming parents like Joe Carofano who cheered on his nine-month-old son Frank during the 1969 contest. 53 Abby Fuschino of Mississauga attended the 1989 Picnic with her husband and three children. As Fuschino explained, simple family-fun was still very much an objective of picnickers, "We enjoy listening to the music, watching folk dances. It's nice to get out." 54 Clearly, from its beginnings in the mid-1960s, the picnic has provided a secure venue for Toronto's diverse communities to celebrate their heritage on their own terms, together with their families.

The picnic's portrayal of Toronto's ethnic groups as family-centered people was critical during the mid 1960s and it has remained an important theme throughout the event's history. The media coverage the picnic received across the city illustrated to Toronto's dominant Anglo-Saxon population that the "ethnics," with their family-oriented values, were not much different from themselves. This was particularly important for Toronto's Italian-Canadian population. This ethnic group had been por-

51 Lombardi, ed., 1987, 19.

52 Doug Owram, Born at the Right Time.

53 Public Archives of Canada, Johnny Lombardi Collection, 45.

54 Campion-Smith, "Clearly."

55 Harney, "Italophobia," 54-58. 
trayed negatively by the Canadian media before World War Two. ${ }^{5}$ After the war, media coverage slowly began to depict the community in a more positive light. The Toronto Star published an article titled "Picnics with an ethnic flair" in 1971. The article featured a number of families including the Oswaldo-Petricca [sic] family. The Star highlighted the way in which the Italian-Canadian family of five bonded by spending "all summer eating and barbecuing on the patio." 56 The column also featured a variety of ethnic cooking recipes which the Star's readers could easily prepare for their own picnics.

There were sentimental features which presented the city's ItalianCanadian population as not only family-oriented but also as noble, hardworking people. Trent Frayne of the Toronto Star wrote, "the Italians are best-off of all Toronto's ethnic groups, it's their willingness to bend their backs for many hours that makes them so." 57 According to Frayne, Toronto's post-war Italian Canadians were to be applauded for achieving so much with so little education. He noted, "Many of them had never seen a traffic light, a television set or a frozen pea." 58 The Toronto Telegram's Helen Slinger wrote an article titled "Courage Takes Root in a Strange Land." It contained much of the same over-romanticized rhetoric regarding the community's hardships when it was published in 1971. In the first part of a fivepart series focusing on the Italian-Canadian community, Slinger noted, "The smooth Anglo-Saxon features that meant Toronto 20 years ago, are sharper now, etched with the lines of ethnic groups that have come here in increasing numbers since World War 2."59 Much of Slinger's column centered on the way in which Italians had come to Canada for both "peace" and "for the children."60 While this shift in discourse did not make the AngloSaxon and Italian-Canadian communities instantly equals, it did foster an important commonality between the two groups which focused on family. Now the "ethnic other" was understood to be acting in a normative manner, similar to all other "good" Canadian citizens. Therefore, the emphasis on nuclear families displayed at the CHIN Picnic reflected a sentiment that was much more widely felt within the larger society.

The picnic was an important public event for many government officials. It functioned as a stage which featured politicians at play and clearly those who attended did not do so merely to enjoy the festivities. For many,

56 Public Archives of Canada, Johnny Lombardi Collection, 109.

57 Public Archives of Canada, Johnny Lombardi Collection, 52.

58 Public Archives of Canada, Johnny Lombardi Collection, 52.

59 Public Archives of Canada, Johnny Lombardi Collection, 111.

60 Public Archives of Canada, Johnny Lombardi Collection, 111. 
attending the CHIN Picnic was critical to gaining the confidence and support of the "ethnic vote." The best illustration of a battle among politicians for voter support occurred at the 1974 picnic. Liberal Prime Minister Pierre Trudeau and Progressive Conservative opponent Robert Stanfield were both closing their individual cross-Canada election campaigns. The picnic was the last stop for the two men and their respective campaigns. Trudeau arrived first with his wife Margaret by his side. The couple was greeted favourably by the crowd as Trudeau exclaimed, "beautiful sun, beautiful music, beautiful dancing, beautiful people ... are you happy?"61 According to one newspaper report, Trudeau received cheers and "good wishes in a score of languages." ${ }^{2}$ The mob which had gathered around the two ignored Trudeau's police escorts and pushed their way through to shake the Prime Minister's hand. Trudeau captivated the picnickers masterfully. When he and his wife danced with the crowd to Greek folk music, Trudeau suddenly took his wife's wide-brimmed hat and placed it on his head. At one point, he took an empty bottle of wine and raised it to his lips to simulate wine drinking. ${ }^{63}$ All these public shenanigans both pleased and amused those in attendance.

Robert Stanfield did not receive the same warm welcome that had been offered to Trudeau by the picnickers. As one newspaper explained, Stanfield was walking "deep in the Liberal land of ethnics." 64 He was accompanied by Ontario Progressive Conservative Premier William Davis. The two men met the nineteen-year-old winner of the CHIN Miss Bikini contest, Marion Stafford. Stanfield and Stafford greeted each other with kisses and posed for pictures before the crowd and members of the media on hand. According to the Toronto Star, picnickers "seemed more interested in the white-bikinied Miss Stafford than in Stanfield."65 Stanfield's lack of popularity among Toronto's ethnic voters was confirmed later when he made his way to the main stage. He was booed by the crowd as Johnny Lombardi formally introduced him. Ontario Premier Bill Davis was jeered even more.66

Public addresses were made by both Trudeau and Stanfield. During these speeches, some members of the crowd were not content with simply passive listening. Julia Nameth of Hamilton was given a rare opportunity to address the Prime Minister and leader of the official opposition. She

61 Public Archives of Canada, Johnny Lombardi Collection, 183.

62 Public Archives of Canada, Johnny Lombardi Collection, 183.

63 Public Archives of Canada, Johnny Lombardi Collection, 183.

64 Public Archives of Canada, Johnny Lombardi Collection, 183.

65 Public Archives of Canada, Johnny Lombardi Collection, 184.

66 Public Archives of Canada, Johnny Lombardi Collection, 184. 
asserted, "Don't fool the people ... All we get are promises two years ago. I go for bread and pay 19 cents a loaf. Now I pay 36 cents. Do something!" 67 While Trudeau ignored Nameth and her complaint, Stanfield attempted to take advantage of the situation by assuring her that he would address the issue of inflation if he was elected to office. Nameth was not convinced, she exclaimed, "Don't Promise! Prove it!"68 The departure of both men from the picnic symbolically foreshadowed the next day's federal election results. Trudeau left Toronto Island on a flashy paddle-wheel steamer replica, while Stanfield departed on a significantly smaller boat. ${ }^{69}$ The following day the Liberals won their first majority government since 1968 and Trudeau achieved his third term as prime minister.

The Trudeau-Stanfield campaign battle is just a small illustration of the political activity which has occurred on the grounds of the CHIN Picnic throughout the event's history. Over time, hundreds of provincial and federal politicians have made appearances or have publicly supported the picnic; this list includes people like Jean Chretien, Mike Harris, Lily Murno, Lincoln Alexander, Joe Clark and David Peterson among others. ${ }^{70}$ Thus, the CHIN Picnic cannot be viewed as an apolitical festival. The event allowed politicians to interact with the growing numbers of ethnic voters to attempt to secure their support. In many instances, those in attendance were allowed to interact with these leaders and express their support or disapproval and, in some rare cases, even their concerns. Most importantly, the participation of politicians at the CHIN Picnic highlighted the fact that Toronto's ethnic communities mattered within Canada's political landscape. The needs and demands of these politically active citizens could not simply be taken for granted.

The commercial aspects of the picnic cannot be overlooked. As mentioned previously, some have criticized CHIN for being overtly commercial. Indeed, over time CHIN has increasingly relied on the financial support of large corporations like Martini and Rothmans as the picnic has expanded in size and grown in cost. Nevertheless, the festival provided an opportunity for local Toronto businesses to connect with the ethnic market. Many of these businesses were owned and operated by members of Toronto's ethnic community. Bad Boy Furniture is the best example of the way in which local business, managed by ethnic groups, took advantage of the publicity generated by the festival.

Bad Boy was operated by Mel Lastman and other members of his fam-

67 Public Archives of Canada, Johnny Lombardi Collection, 175

68 Public Archives of Canada, Johnny Lombardi Collection, 175

69 Public Archives of Canada, Johnny Lombardi Collection, 183.

70 Lombardi, ed., 1987; Lombardi, ed., 1984, Zito, ed., 1996. 
ily. Lastman grew up as the son of Jewish immigrant parents from Poland in one of Toronto's early culturally-diverse neighbourhoods, Kensington Market. From a young age he understood how to connect with Toronto's ethnic commercial market when he began selling groceries at his parent's store, Starkman's Fruits and Vegetables, on Baldwin Street in the Market. ${ }^{71}$ He was a creative businessman who, in 1955 at the age of twenty-two, bought his first appliance store. In order to entice customers to purchase appliances from him he carried out "market research" by following an ice truck around Toronto and noting the homes where ice was delivered. Lastman returned to these homes the following day to convince householders that his modern refrigerators were cheaper and more convenient than having ice delivered to their door step. His plan was effective and his business boomed. ${ }^{72}$ Lastman was an ideal business partner for Lombardi because they both understood the immigrant experience vicariously through the struggles of their parents. In 1967, Bad Boy Furniture became the CHIN Picnic's first official sponsor and Lombardi and Lastman engaged in the performance of Abbot and Costello-like comedy skits to promote their goods and services. ${ }^{73}$ These two men were pioneers of the post-war commerce of ethnicity in the City of Toronto.

Several of Toronto's ethnic-owned and -operated businesses used the picnic to promote their goods or services to the "ethnic market." Many of these groups were connected to the city's Italian-Canadian community. In 1984, the soft drink maker Mio Gassosa placed an advertisement in a CHIN Picnic programme booklet. The company reminded picnickers that they had been "serving Ontario residents for over 20 years" with free home delivery. ${ }^{74}$ They used their ethnic background as a selling point, asserting "Drink Mio. The Soft Drink Italian Style."75 Dufferin Tile highlighted the way in which the company was an "Importer and Distributor of Quality Italian Ceramics."76 Woodbridge car dealership Pine Tree Lincoln Mercury used the name and popular reputation of their Italian-Canadian owner, Al Palladini, as its connection to the Italian-Canadian community. ${ }^{77}$ Some companies, like La Torre Del Formaggio bakery, opted for a mezzo-mezzo

71 Welsh, “The Salesman ," GT01.

72 Welsh, "The Salesman ," GT01

73 Welsh, "The Salesman ," GT01.

74 Lombardi, ed., 1984, 31.

75 Lombardi, ed., 1984, 31.

76 Lombardi, ed., 1984, 23.

77 Lombardi, ed., 1984, 22.

78 Lombardi, ed., 1984, 31. 
(half and half) advertising format which provided text in both English and Italian.78 While cheese specialty shop Ferrante Cheese MFG advertised strictly with Italian-language text. ${ }^{79}$ All of these businesses were attempting to attract the city's growing "ethnic market" regardless of the various techniques they utilized.

Mainstream Canadian society took note of the Italian-Canadian community's growing purchasing power. The Monetary Times reported in 1968 that Italian Canadians represented an estimated economy of seven-hundred million dollars. The journal explained the manner in which this lucrative market was "chipping away at Canada's Anglo-Saxon Protestant establishments." 80 While the work of Robert Harney illustrates discrimination against Italians Canadians which existed in Canadian society before World War II, the report in the Times provides evidence that a change in mainstream attitudes was slowly occurring. ${ }^{81}$ The journal attributed the postwar success of the ethnic group to their acceptance of "Canada's mosaic approach" 82 and went on to note that "Italians in Canada" were happy to be living in a free and democratic nation, asserting "Italians respond to this freedom by becoming responsible citizens." 83 Mainstream Canadian society was well aware of the economic potential embodied by ethnic groups like Italian Canadians, an awareness which explains why so many large and "non-ethnic" corporations like Pizza Pizza, Bell, and Labatt used the picnic to promote their businesses. ${ }^{84}$ Therefore, both ethnic and non-ethnic companies engaged actively in the competitive post-war consumer market and new Canadians benefited directly from this process. They had a wide variety of products which were available for their consumption and they negotiated their identities, in part, through that consumption in the postwar commerce of ethnicity. The market allowed them to chose between products like Brio Chinotto and Coca-Cola or between Peroni and Molson, among others.

Celebrating Canada was another important feature emphasized at the CHIN Picnic. In a 1984 Picnic programme booklet, Lombardi noted, "How exciting it is to look around us and see the diversity of our city, the distinctive neighbourhoods, and to know that all these different elements

79 Lombardi, ed., 1984, 56.

80 Public Archives of Canada, Johnny Lombardi Collection, 37.

81 Harney, Italophobia.

82 Public Archives of Canada, Johnny Lombardi Collection, 37.

83 Public Archives of Canada, Johnny Lombardi Collection, 37.

84 Zito, ed., 1996.

85 Lombardi, ed., 1984, 17. 
of interest all have one thing in common ... CANADA-our home and native land!" 85 Lombardi constantly worked to reinforced Canadian patriotism at the picnic and his rhetoric increased as the picnic grew from a one-day event to a Canada Day weekend celebration. On 1 July 1995, Lombardi made a clear political statement at the festival. He urged picnickers to look up at a massive Canadian maple leaf flag which blew in the wind high above the crowd. He exclaimed, "Look at that flag-it has meant something to all of us. Long live our Canada with 10 provinces and no separation." 86 Lombardi's pro-nationalist comment came during a time of great tension between Québec and the rest of the nation: in October of that year the province would hold its second independence referendum. Lombardi attempted to associate the "ethnic other" with Canadian national identity by normalizing multicultural diversity. He explained the way in which the picnic was "a celebration of differences. And we don't fight over those differences - we celebrate them and we celebrate Canada's diversity. It's a weekend for families." $87 \mathrm{He}$ extended his patriotism to Canadian businesses as well including, on one occasion, an exhortation to picnickers to "think first about buying a Canadian car made by Canadians for Canadians. Help Canadian carmakers they've got people to feed." 88 This pro-Canada discourse was supported by politicians who attended the event. For example, Toronto City councillors such as Maria Augimeri would meet and greet new Canadian citizens at the festival on Canada Day. Many of these same new Canadians had just received their citizenships earlier in the day. 89

The picnic became a Canada Day weekend ritual for many Torontonians. Walter Jurowski told the Globe and Mail in 1998 that he had been attending the picnic for over twenty years. He explained, "It gets everybody together, they're in a good mood." 90 Ken Eller and Cheryl Giraudy were also interviewed by the same newspaper. They came to the picnic with their two-year-old daughter Amelia who sported a temporary maple leaf tattoo on her forehead. Like Jurowski, the couple made no direct references to ethnicity or ethnic identity. Instead, Eller presented the picnic as an event organized to "celebrate Canada's birthday." 91 Marlene Gray enjoyed attending the event for several reasons. She told the Toronto

86 van Rijn, "What a birthday Bash!," A1.

87 van Rijn, "What a birthday Bash!," A1.

88 Beddoes, "A topsy-curvey feast...," 8.

89 James, "Councillors...,"1993, A4.

90 Honey, "Canadians new and old...," A10.

91 Honey, "Canadians new and old...," A10. 
Star in 1994, "This is our fourth or fifth time at the picnic. You get a sense of being patriotic, you know, watching the flag being raised. And it's so nice to have all the different ethnic groups here." 92 These three examples represent the many people who attended the festival to champion not only cultural diversity but also Canadian national identity. Picnickers-like the event's organizers and public officials who attended-also worked to fuse these two distinct concepts. They illustrate the way in which ethnicity and traditional Canadian culture could be practiced and celebrated simultaneously through a negotiated process of identity construction. Those who attended could choose the manner in which they presented themselves through: the clothing they wore, the food and beverages they consumed, the activities they took part in, the people they interacted with and the languages they spoke.

Ultimately, CHIN radio must be seen as a vehicle which helped its listeners to negotiate and form their own ethnicity on a daily basis, while at the same time it served to help new Canadians to understand Canadian culture and customs. CHIN's listeners played a vital role in influencing the station's daily programming, which offered them a mixture of both news and entertainment. The station's cultural festivities allowed these listeners to display and celebrate their self-created identities in public. This is important in particular for Toronto's Italian-Canadian community. It allowed them to remain ethnically unique as a group, while simultaneously showing mainstream Canadian society that they were family-oriented, politically relevant and pro-nationalist. In addition, the station created commercial opportunities allowing various groups and individuals to take part in the post-war commerce of ethnicity, which demonstrated the purchasing power possessed by ethnic groups after World War II. While much of the negotiation of ethnicity was a group-oriented experience, the heart of the CHIN case study lies within the psyche of the individual who actively chose to tune in. After all, no station can exist without an audience.

\section{Halton Catholic District School Board}

\section{WORKS CITED}

\section{Primary Sources}

Board of Broadcast Governors. "Public Announcement: Foreign-Language Broadcasting,” 22 June 1962.

92 van Rijn, "Oh Canada...," A4. 
CHIN Radio. History of CHIN, 1982. Archives of Ontario, C258-1-0-9, video recording, 48 minutes.

Canadian Radio-television and Telecommunications Commission [CRTC]. Ethnic Broadcasting: Public Hearings, 1985.

Gibbons, E.J. Gibbons to Johnny Lombardi, letter 7 March 1967, CHIN Radio Private Collection.

Lombardi, Johnny, ed. Johnny Lombardi Presents the $18^{\text {th }}$ Annual International Picnic

June 29 to July 2 [1984], CHIN Picnic Programme Booklet, CHIN Radio Private Collection.

Lombardi, Johnny, ed. Johnny Lombardi Presents the 21 th Annual International Picnic

July 1-5 [1987], CHIN Picnic Programme Booklet, CHIN Radio Private Collection, p. 19.

Lenny Lombardi interview. Mike Amatiello interview with Lenny Lombardi, 29 May 2009, author's collection.

Umberto Manca interview. Mike Amatiello interview with Umberto Manca, 23 July 2009, author's collection.

Parkinson, Ralph. Parkinson to Gil Christie, letter 15 May 1969, CHIN Radio Private Collection.

Potter, Aubrey V. Potter to Johnny Lombardi, letter, 20 October 1969, CHIN Radio Private Collection.

Public Archives of Canada. Ottawa. Johnny Lombardi Collection: 1950-1974, textual records, microfilm.

Toronto Transit Commission. Toronto Transit Commission to Johnny Lombardi, letter, 2 August 1968, CHIN Radio Private Collection.

Zito, Madeline, ed. 30 th Anniversary: CHIN International Picnic, June 29 to July 1 [1996], CHIN Picnic Programme Booklet, CHIN Radio Private Collection.

\section{Published Sources}

Beddoes, Dick. "A topsy-curvey feast for the senses" The Globe and Mail (7 July 1980): 8.

Campion-Smith, Bruce. "Clearly, Michael Wilson wasn't the featured entertainer" Toronto Star (3 July 1989): HO2.

Conzen, Kathleen Neils, et al. "The Invention of Ethnicity: A Perspective from the U.S.A.” Journal of American Ethnic History 12.1 (1992): 3-34.

Evasuk, Stasia. “Johnny Lombardi ready for CHIN's 122 picnic." Toronto Star (30 June 1988): D3.

Harney, Robert F. "Italophobia: an English-speaking Malady?" Polyphony: The Bulletin of the Multicultural History Society of Ontario 7.2 (1985): 54-58.

Hayward, Mark. "Global Italy: Media, Identity and the Future of the NationState," PhD diss., University of North Carolina, 2008.

Honey, Kim. "Canadians new and old mark July 1 Canada Day: Both citizens and those who dream of citizenship turned out for celebrations that often focused on 
the country's immigrant roots" The Globe and Mail (2 July 1998): Metro A10. James, Royson. "Councillors tell critics to but [sic] out of bikini fest" Toronto Star (22 May 1993): A4.

Kingwell, Mark. "Johnny Lombardi at 69 is keeping his CHIN up" The Globe and Mail (29 June 1985): M5.

MacNiven, Elina. "The king of radio for new Canadians Johnny Lombardi displays old world hospitality at the annual CHIN Picnic" The Globe and Mail (2 July 1982): P11.

Owram, Doug. Born at the Right Time: A History of the Baby Boom Generation. Toronto: University of Toronto Press, 1996.

Ricci, Nino. "A Critique of Sorts" Eyetalian 44 (1997): 44.

Ricci, Nino. "Confession of a Closet Neo-Con" Eyetalian 34 (1996): 36.

Rijn, Nicolas van. "What a birthday Bash! It's Happy $128^{\text {th }}$, Canada celebrates $128^{\text {th }}$ with parties across the country" Toronto Star (2 July 1995): A1.

Rijn, Nicolas van. "Oh Canada, what a perfect day. 'This is what it's all about different people, different races" Toronto Star (2 July 1994): A4.

Serge, Joe. "CHIN's Johnny Lombardi still going strong at 74" Toronto Star (25 June 1990): B3.

Stein, David Lewis. "Lombardi is still entitled to our gratitude and respect" Toronto Star (11 June 1993): A27.

Thoroski, Cynthia. "Adventures in Ethnicity: Consuming Performances of Cultural Identity in Winnipeg's Folkorama" Canadian Folklore 19.2 (1997): $105-11$.

Welsh, Moira. “The Salesman - Mel Lastman's journey from Kensington Market to City Hall has been driven by his single greatest talent" Toronto Star (11 November 2000): GT01. 